\title{
Mangrove Riau: sebaran dan status perubahan
}

\author{
Yossi Oktorini ${ }^{1}$, Eko Prianto ${ }^{2}$, Vini Volcherina Darlis ${ }^{3}$, Rahmatdillah $^{4}$, Miswadi $^{5}$, \\ Romie Jhonnerie $^{6 *}$ \\ ${ }^{1,3}$ Jurusan Kehutanan, Fakultas Pertanian, Universitas Riau \\ ${ }_{1,2,4,5,6}$ Mangrove Research Institute, Pekanbaru \\ ${ }^{2}$ Jurusan Manajemen Sumberdaya Perairan, Fakultas Perikanan dan Kelautan, Universitas Riau \\ ${ }^{4}$ Abata Karya Nusa, Consultan \\ ${ }^{6}$ Jurusan Pemanfaatan Sumberdaya Perikanan, Fakultas Perikanan dan Kelautan, Universitas Riau \\ *Koresponden E-mail: romie.jhonnerie@lecturer.unri.ac.id
}

(Diterima: 27 Agustus 2021|Disetujui: 28 Desember 2021|Diterbitkan: 31 Januari 2022)

\begin{abstract}
The need for data and information is an essential issue in sustainable mangrove management. The availability of data from authorized institutions is essential considering the reliability and consistency of the data, both to process techniques and data availability. This study used national mangrove and landcover data produced by the Ministry of Environment and Forestry through online services. 11 data series (2000 - 2019) obtained through the Representational State Transfer (REST) Application Programming Interface (API) service. Application of spatial analysis of vector data through geoprocessing tools and attribute data management to determine the distribution and changes in mangrove cover and the factors that trigger changes. Estimated data indicate a 13.4\% decline in mangroves in Riau Province, with an average decline of 2,495.9 hectares/year. Over $98 \%$ of mangrove changes into other functions are caused by human behavior towards mangroves; we need a genuine attitude to preserve the mangroves of Riau Province for the future.
\end{abstract}

Keywords: mangrove; riau province; mangrove distribution; mangrove changes; landcover

\section{PENDAHULUAN}

Mangrove dapat dijumpai di zona intertidal sepanjang pantai tropis (Garcia \& Martins, 2021) dan subtropis (Garcia \& Martins, 2021), dan memainkan peran penting di zona pesisir dengan menyediakan berbfagai jasa ekosistem yang berbeda untuk populasi pesisir (van Oudenhoven et al., 2015). Misalnya, mangrove penting dalam siklus karbon global (Alongi \& Mukhopadhyay, 2015) dan pengurangan konsentrasi gas rumah kaca (GRK) di atmosfer (Cameron et al., 2019). Mangrove merupakan penyerap karbon yang efisien dengan menyerap karbon dalam biomasa dan sedimen di atas tanah dan di bawah tanah (Jennerjahn, 2020). Mangrove juga mampu menstabilkan garis pantai (Critchley et al., 2021) dan melindungi tanah dari erosi (Besset et al., 2019). Mangrove juga memberikan kontribusi yang signifikan bagi mata pencaharian penduduk pesisir melalui perikanan ( $\mathrm{Zu}$ Ermgassen et al., 2020), sumber kayu dan kayu bakar (Rasquinha \& Mishra, 2020), dan hasil hutan bukan kayu (Aziz et al., 2016).

Goldberg et al. (2020) mengestimasi hilangnya mangrove dunia sebesar $3.363 \mathrm{~km}^{2}(2,1 \%)$ tahun 2000 dan 2016, dengan laju tahunan rata-rata $0,13 \%$. Aktivitas manusia menjadi penyebab utama hilangnya mangrove $(62 \%)$ dari total area kehilangan mangrove global. Aktifitas manusia dapat dibagi menjadi: 1) konversi mangrove menjadi lahan berbasis komoditas, diantaranya padi, udang dan kelapa sawit berkontribusi sebesar 47\% (1.596 $\pm 42 \mathrm{~km} 2)$; 2) konversi lahan menjadi lahan non-produktif sebesar $12 \%(398 \pm 29 \mathrm{~km} 2)$; 3i) konversi menjadi lahan reklamasi untuk permukiman sebesar 3\% (96 $\left.\pm 15 \mathrm{~km}^{2}\right)$. Sisa 38\% dari total mangrove yang hilang disebabkan oleh penyebab alami. Erosi garis pantai merupakan persentase kerugian global tertinggi kedua pada 27\% $\left(912 \pm 41 \mathrm{~km}^{2}\right)$ dan peristiwa cuaca ekstrem menyumbang $11 \%$ kerugian $\left(361 \pm 31 \mathrm{~km}^{2}\right)$. Indonesia merupakan negara dengan tutupan mangrove terluas di dunia (Bunting et al., 2018; Giri et al., 2011; Spalding et al., 2010) dan mengalami kehilangan mangrove tertinggi terutama karena konversi mangrove menjadi budidaya perikanan (Richards \& Friess, 2016). Jika kerusakan ini terus berlanjut, maka akan terjadi hilangnya ekosistem unik yang memiliki multi manfaat secara ekologis, sosial dan ekonomi (Arifanti, 2020).

Sejak tahun 1982 sampai 1992, Provinsi Riau memiliki sekitar 5,9\% sampai 14,5\% (Sukardjo, 2000). Data terbaru menunjukkan provinsi ini memiliki luas mangrove sebesar 213.459,21 hektar (6,4\%) (Rahadian et al., 2019), dari luas dan persentase tersebut menjadikannya sebagai provinsi terbesar ketiga untuk sebaran mangrove di Indonesia. Seperti daerah lainnya, mangrove di Provinsi Riau telah banyak terjadi perubahan kualitas dan kuantitas. Namun literatur yang menguak 
fenomena tersebut masih terbatas dan bersifat sporadis (Jhonnerie et al., 2007; Jhonnerie et al., 2014). Keterbatasan tersebut disebabkan oleh sarana dan prasarana yang tersedia serta desiminasi data. Meskipun saat ini infrastruktur desiminasi data dan informasi sangat mendukung, namun banyak pihak membatasinya, sehingga data hanya dapat dilihat tanpa memberikan kesempatan pihak lain untuk menganalisis lebih lanjut (Margono et al., 2016).

Kementerian Lingkungan Hidup dan Kehutanan (KLHK) merupakan salah satu institusi negara yang menyediakan data (peta) digital mangrove, selain beberapa kementerian dan badan negara lainnya (Hartini et al., 2010). Melalui ketersediaan citra satelit Landsat, sejak tahun 2000, KLHK telah memproduksi peta tutupan lahan (termasuk tutupan mangrove) Indonesia dalam interval tiga tahun. Dengan konsistensi teknik pengolahan data dan bersumber dari satu institusi maka data tersebut layak untuk digunakan dalam pemantauan mangrove Provinsi Riau. Tujuan penelitian ini adalah untuk mengetahui sebaran dan status perubahan mangrove di Provinsi Riau selama 19 tahun $(2000-2019)$.

\section{BAHAN DAN METODE}

Daerah studi berada di Provinsi Riau di Pulau Sumatera, Indonesia $\left(100^{\circ} 00^{\prime}-105^{\circ} 05^{\prime} \mathrm{BT}\right.$ dan $01^{\circ} 05^{\prime}$ dan $02^{\circ} 25^{\prime}$ LS). Iklimnya khas tropis khatulistiwa dengan suhu rata-rata tahunan $22-31^{\circ} \mathrm{C}$ dan curah hujan tahunan antara 2.500 dan $3.000 \mathrm{~mm}$. Musim kemarau biasanya dari bulan Juni sampai Oktober, dan musim hujan dari bulan November sampai April/Mei. Penutupan tanah daratan meliputi hutan alam (hutan kering di atas tanah mineral, hutan rawa gambut, dan bakau), perkebunan (kelapa sawit, karet, akasia, kelapa dan lain-lain.), lahan kosong, padang rumput, dan perkotaan. Spesies dominan utama dari hutan rawa gambut alami adalah pohon berdaun lebar yang selalu hijau seperti Shorea spp. dan Swintonia spp. (Momose \& Shimamura, 2002).

Data diperoleh pada laman Forest 2020 Indonesia melalui REST Application Programming Interface (API) menggunakan QGIS 3.10.10-A Coruña. Data tersebut diproduksi oleh KLHK berbasis citra satelit Landsat 7 dan 8 (Margono et al., 2016). Forests 2020 adalah sebuah investasi Badan Antariksa Inggris, sebagai bagian dari Program Kemitraan Internasional (International Partnership Programme), untuk membantu melindungi dan memulihkan hutan tropis dengan meningkatkan pemantauan hutan di enam negara mitra (termasuk Indonesia) melalui penggunaan citra satelit. Data yang diunduh terdiri dari dua tema yaitu tema mangrove primer (mangrove yang belum mendapatkan gangguan manusia misalnya bekas penebangan, pada beberapa lokasi, hutan mangrove primer berada lebih ke pedalaman) dan mangrove sekunder (mangrove yang telah mendapat gangguan baik berupa bekas tebangan, alur jalan, tanaman ex-situ), meliputi seluruh wilayah Indonesia. Data disimpan dalam format shapefile (.shp), dengan sistem proyeksi peta WGS1984 World Mercator. Seri ketersediaan data sebanyak 11 seri tahun data, yaitu tahun 2000, 2003, 2006, 2009, 2011, 2012, 2013, 2016, 2017, 2018 dan 2019. Tema mangrove primer dan sekunder selanjutnya digabung (merge) menjadi satu tema yaitu mangrove. Pada akhirnya dihasilkan 11 tema mangrove yang berasal dari setiap tahun ketersediaan data. Kesebelas data tersebut disatukan melalui operasi spasial union. Data dengan sumber yang sama pernah dimanfaatkan oleh Adrianto et al. (2020) untuk mengkaji deforestasi hutan di Indonesia.

Untuk mempermudah pelacakan poligon asal seri tahun data maka setiap seri tahun data diberikan atribut pengenal, melalui persamaan berikut:

$$
A T_{n}=1 * 10^{-n}
$$

AT adalah atribut pengenal seri tahun ke-n; $j$ adalah jumlah seri tahun data; $n$ adalah seri data ke-n. Misalnya tahun 2000, merupakan seri tahun ke satu dan jumlah seri data yang tersedia adalah 11. Maka atribut pengenal data tahun 2000 (seri data pertama) adalah 10000000000 dan atribut pengenal data tahun 2019 (seri data kesebelas) adalah 1. Untuk mengetahui perubahan (penambahan dan pengurangan) luasan dan sebaran mangrove maka seluruh atribut pengenal yang telah dihasilkan tersebut dijumlahkan. Mangrove yang bertambah diindikasikan oleh angka satuan pada bilangan hasil penjumlahan atribut pengenal. Angka 1 pada bilangan tersebut mengindikasikan penambahan dan angka 0 mengindikasikan pengurangan luas dan sebaran mangrove sementara mangrove yang tidak mengalami perubahan sejak tahun 2000 - 2019 diindikasikan oleh bilangan 11111111111.

Perubahan penutupan lahan dari kelas mangrove menjadi penutup lahan lainnya diperoleh melalui overlay data mangrove tahun 2000 dengan data penutupan lahan tahun 2019, menggunakan tool union.

\section{HASIL DAN PEMBAHASAN}

Eksploitasi kayu bakau komersial dimulai selama operasi perusahaan perdagangan Belanda VOC (Vereenigde Oost-Indische Compagnie) di Indonesia pada tahun 1700-an. Namun, eksploitasi besar-besaran dimulai pada akhir tahun 1800-an, seiring dengan perdagangan internasional yang berkembang pesat antara Indonesia, Eropa, dan AS serta dengan Singapura sebagai pelabuhan utama. Selama periode ini, masyarakat di sepanjang pantai Riau melakukan penebangan mangrove untuk ekspor tanin ke Eropa dan AS. Ekspor arang, konstruksi, dan kayu bakar ke Singapura (Ilman et al., 2016). Sementara Ilman et al. (2011) menyatakan kajian-kajian awal mangrove di Indonesia mulai dari awal abad ke-20, oleh van Bodegom 
tahun 1929 tentang 'Hutan banjir di wilayah Riouw dan pinggiran kota' (Giesen et al., 2007).

Sebaran mangrove Provinsi Riau dapat dijumpai di seluruh habitat mangrove yaitu: sepanjang garis pantai (Giri et al., 2011), estuaria (Marley et al., 2020) dan sungai (Daniel \& Robertson, 1990). Keseluruhan habitat tersebut merupakan daerah intertidal, yang dicirikan oleh faktor lingkungan yang bervariasi seperti suhu, salinitas, sedimentasi dan arus pasang surut. Daerah pesisir Provinsi Riau merupakan muara bagi empat sungai besar, yaitu: Sungai Rokan, Siak, Kampar dan Indragiri. Sungai-sungai tersebut berkontribusi sebagai penyumbang sedimen yang berasal dari daratan dalam bentuk suspensi yang kaya akan kandungan nutrien dan bahan organik sehingga menjadikan substrat yang sesuai untuk pertumbuhan dan perkembangan mangrove lebih baik (Mustafa Kamal et al., 2020). Sementara berdasarkan administrasi, mangrove Provinsi Riau tersebar pada tujuh kabupaten/kota pesisir, yaitu: Indragiri Hilir (104.570,6 hektar), Kepulauan Meranti (27.998,9 hektar), Bengkalis (25.373,4 hektar), Rokan Hilir (21.708,0 hektar), Dumai (4.628,5 hektar), Pelalawan (2.037.9 hektar) dan Siak (296,96 hektar).

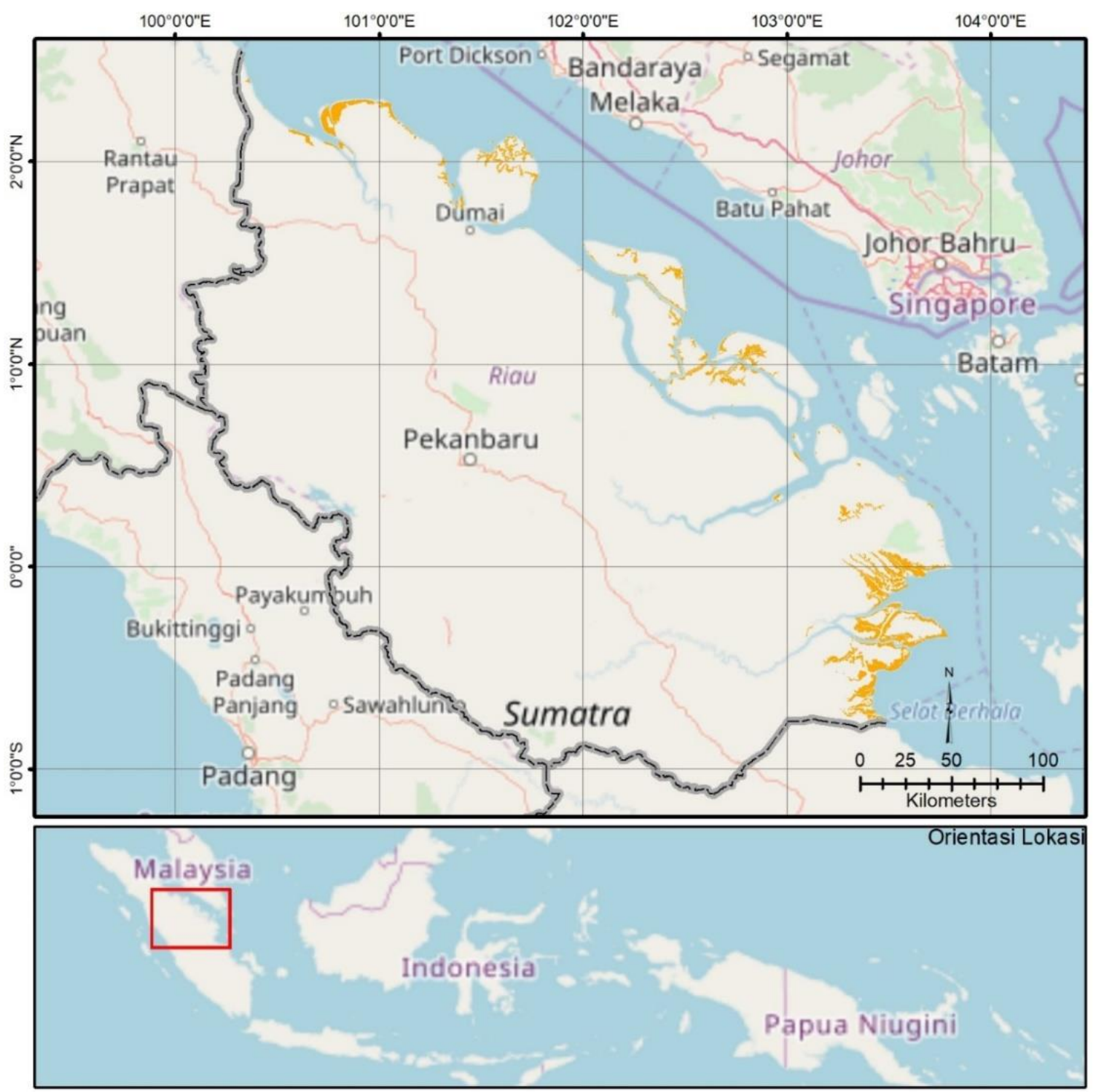

Gambar 1. Peta lokasi penelitian, Provinsi Riau dan sebaran mangrove tahun 2019

Pemetaan mangrove global dilakukan Spalding et al. (2010); Giri et al. (2011); Richards and Friess (2016); Bunting et al. (2018). Sementara pemetaan mangrove nasional telah diinisiasi melalui penelitian Martosubroto and Naamin (1977) dan mangrove
Provinsi Riau sudah menjadi perhatian nasional melalui kajian tersebut. Luas mangrove Provinsi Riau berkisar antara 75.000 - 343.750 hektar, berdasarkan perhitungan penelitian sebelumnya $(1950$ - 2017), 
perhitungan lainnya dapat merujuk penelitian Rahadian et al. (2019). Sementara penelitian ini memperkirakan luas mangrove Provinsi Riau berkisar antara 186.614,3 - 161.655,5 hektar (mulai tahun 2000 2019) (Tabel 1).

Peta sebaran mangrove Riau tersebut masih menyisakan pertanyaan (2000-2016), khususnya pada garis pantai Pulau Sumatera yang hanya dapat dijumpai dari Tanjung Lumba-lumba hingga bagian perkotaan Kota Dumai, selanjutnya mulai dari Tanjung Dato, Kecamatan Mandah Indragiri Hilir hingga perbatasan Provinsi Jambi. Sementara pada garis pantai lainnya mangrove hanya berupa kumpulan kecil hingga tidak dijumpai. Kekontrasan terjadi jika dibandingkan dengan data sebaran mangrove Spalding et al. (2010), Giri et al. (2011), dan Bunting et al. (2018).

Tabel 1. Luas (hektar) mangrove Provinsi Riau dari tahun 1950-an hingga tahun 2019

\begin{tabular}{lll}
\hline Tahun & Luas & Sumber \\
\hline 1950 'an & $343.750,00$ & $\begin{array}{l}\text { Martosubroto dan Naamin } \\
\text { (1977) }\end{array}$ \\
1990 & $276.000,00$ & Choong et al (1990) \\
1996 & $167.334,20$ & Bunting et al (2018) \\
2000 & $186.614,30$ & Penelitian ini \\
2003 & $183.208,10$ & Penelitian ini \\
2006 & $180.952,10$ & Penelitian ini \\
2007 & $165.293,20$ & Bunting et al. (2018) \\
2009 & $206.292,00$ & Penelitian ini \\
2009 & $165.610,10$ & Bunting et al. (2018) \\
2010 & $97.941,60$ & Spalding et al. (2010) \\
2010 & $166.902,60$ & Bunting et al. (2018) \\
2011 & $141.612,60$ & Giri et al. (2011) \\
2012 & $164.822,90$ & Penelitian ini \\
2013 & $164.616,80$ & Penelitian ini \\
2015 & $165.767,40$ & Bunting et al. (2018) \\
2016 & $169.744,30$ & Penelitian ini \\
2016 & $166.204,40$ & Bunting et al. (2018) \\
2017 & $172.180,30$ & Penelitian ini \\
2018 & $171.198,00$ & Penelitian ini \\
2019 & $161.655,50$ & Penelitian ini \\
\hline
\end{tabular}

\section{Perubahan Mangrove}

Luas mangrove di Provinsi Riau cenderung menurun dari tahun 2000 hingga 2019. Rata-rata penurunan luas per tahun adalah 2.495,9 hektar. Puncak penurunan mangrove terjadi pada tahun 2009 (perubahan dari tahun 2006 - 2009), sebesar 13.014,20 hektar sementara penambahan luas hanya terjadi pada dua tahun yaitu 2016 (perubahan dari tahun 2013 2016) sebesar 5.127,50 hektar dan 2017 (perubahan dari tahun 2016 -2017) sebesar 2.436,00, dan pada dua tahun berikutnya terjadi penurunan luas hingga menukik cukup tajam di tahun 2019 (Gambar 2).

Provinsi Riau termasuk salah satu dari tiga provinsi yang paling tereskploitasi mangrovenya berdasarkan kajian sebelumnya luasannya mencapai 400.000 hektar (Silvius et al. 1987), namun Ilman et al. (2016) mencoba membatasi perhitungannya, sejak tahun 1923 - 1936, 50\% mangrove di Riau, Sumatera Utara dan Aceh atau sekitar 200.000 hektar telah mengalami degradasi atau deforestasi. Pada akhir tahun 1970 sebagian besar kawasan mangrove yang terdegradasi tersebut (75\%) kemungkinan besar telah direkolonisasi oleh estimasi peneliti-peneliti berikutnya termasuk penelitian ini.

Selama 19 tahun pengamatan, pengurangan luas mangrove (48.038,55 hektar) terjadi lebih besar dibandingkan penambahan luas (15.998,53 hektar). Pengurangan terbesar terjadi di Kabupaten Indragiri Hilir $(37,2 \%)$ dan Rokan Hilir (35,2\%). Sementara penambahan luas mangrove tersebar dijumpai pada kedua kabupaten tersebut. Sementara mangrove yang bertahan berada seluas $145.656,96$ hektar, persentase bertahan terbesar berada di Kabupaten Indragiri Hilir $(60,7 \%)$ dan Kepulauan Meranti (17,5\%) (Tabel 2). Hal menarik lainnya adalah perubahan mangrove Kota Dumai, meskipun berdasarkan luas tidak melebihi luas Kabupaten Indragiri Hilir dan Rokan Hilir, namun persentase lokal, Kota Dumai mengalami kehilangan mangrove yang paling tinggi dan kejadian tersebut hanya berlangsung dalam waktu satu tahun (2016-2017).

Tabel 2. Luas (hektar) pengurangan, penambahan dan mangrove yang bertahan di Provinsi Riau

\begin{tabular}{lrrr}
\hline Kabupaten & Berkurang & Bertambah & \multicolumn{1}{c}{ Tetap } \\
\hline Bengkalis & $2.514,15$ & $1.83,17$ & $22.488,52$ \\
Dumai & $5.085,49$ & 313,05 & 438,17 \\
Indragiri & $17.856,66$ & $6.213,62$ & $88.457,95$ \\
Hilir & & & \\
Kepulauan & $3.780,40$ & $2.550,62$ & $25.552,46$ \\
Meranti & & & \\
Pelalawan & $1.501,26$ & 816,23 & $1.427,31$ \\
Rokan & $16.904,16$ & $4.012,13$ & $7.003,82$ \\
Hilir & & & \\
Siak & 423,43 & 258,82 & 288.72 \\
Jumlah & $43.038,35$ & $18.998,53$ & $145.656,96$ \\
\hline
\end{tabular}

Mangrove di Provinsi Riau berubah menjadi 12 kelas penutup lahan lainnya (Tabel 3). Perubahan tersebut diakibatkan oleh faktor-faktor antropogenik (lebih dari 98\%) (Choong et al., 1990), meskipun pada akhirnya menjadi kelas penutup lahan yang sifatnya alami misalnya badan air, rawa dan hutan rawa sekunder. Perubahan mangrove terbesar menjadi kelas penutup lahan belukar rawa (BR), kemudian diikuti oleh kelas perkebunan $(\mathrm{Pn})$, perkebunan lahan kering campuran (PLkc), sawah (Sh), tanah terbuka (TT), hutan rawa sekunder (HRs), badan air (BA), rawa (Ra), 
permukiman (Pn), tambak (Tk) dan perkebunan lahan kering (PLk). Faktor-faktor pemicu perubahan mangrove tersebut dapat dikelompokkan ke dalam: pengembangan tambak, ekspansi dan pengambangan kelapa sawit, pengembangan budidaya pertanian, pengembangan daerah pantai, penebangan mangrove (logging), aktifitas pertambangan, bencana alam (Ilman et al., 2016; Ilman et al., 2011; Richards \& Friess, 2016).

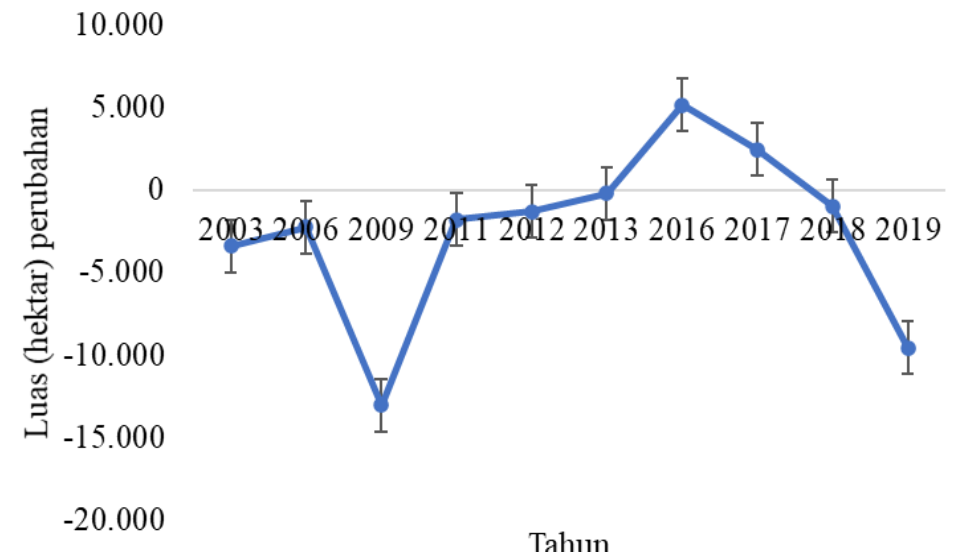

Gambar 2. Dinamika perubahan luas mangrove dari tahun 2000 - 2019. Nilai negatif mengindikasikan terjadinya pengurangan luas dan sebaliknya nilai positif mengindikasikan terjadinya penambahan luas. Bar pada grafik mengindikasikan standar error.

Mangrove telah dieksploitasi secara sistematis di Indonesia sejak tahun 1800 , terutama untuk pengembangan budidaya perikanan air payau (tambak udang) dan untuk pemanenan kayu. Di Sumatera, meskipun masih terdapat hutan bakau yang luas namun kawasan tersebut tidak cocok untuk tambak karena perbedaan tinggi pasang surut yang besar khususnya di Riau (Ilman et al., 2016). Meskipun demikian dengan perkembangan teknologi dan inovasi saat ini luas rata-rata tambak di Provinsi Riau dari data Badan Pusat Statistik dari tahun 2005 - 2016 seluas 1.240 hektar dan sebagian besar telah merubah fungsi mangrove.

Tabel 3. Perubahan mangrove menjadi kelas penutup lahan lainnya, dari tahun 2000 - 2019 di Provinsi Riau

\begin{tabular}{|c|c|c|c|c|c|c|c|c|c|c|c|c|c|}
\hline Kabupaten & $\mathrm{BA}$ & BR & HRs & HT & $\mathrm{Pn}$ & $\mathrm{Pa}$ & PLk & PLkc & $\mathrm{Ra}$ & $\mathrm{Sh}$ & Tk & TT & Jumlah \\
\hline Bengkalis & 29,0 & 86,1 & 18,5 & 20,2 & & 137,6 & 25.4 & 907,9 & & & 85,7 & 69,8 & $2.150,4$ \\
\hline Dumai & & $1.597,5$ & & $1.644,0$ & 22,2 & 432,3 & & 371,4 & & 17,7 & 36,1 & 32,4 & $4.131,4$ \\
\hline Indragiri Hilir & 3,4 & $6.921,4$ & & & 48,5 & $6.641,2$ & 14.9 & $2.083,4$ & 38,0 & 40,3 & & 376,1 & $13,530.2$ \\
\hline $\begin{array}{l}\text { Kepulauan } \\
\text { Meranti }\end{array}$ & 8,7 & 775,7 & 183,9 & & 36,9 & 425,8 & & 300,6 & & & & 563,8 & $2.295,3$ \\
\hline $\begin{array}{l}\text { Pelalawan } \\
\text { Rokan Hilir } \\
\text { Siak }\end{array}$ & 157,3 & $\begin{array}{r}214,8 \\
6.404,6\end{array}$ & 153,6 & & $\begin{array}{r}2,8 \\
13.7\end{array}$ & $\begin{array}{r}12,8 \\
6.139,7\end{array}$ & & $\begin{array}{r}205.4 \\
643,4 \\
1,7\end{array}$ & 124,8 & 834,9 & & $\begin{array}{r}18,4 \\
102,0 \\
3,2\end{array}$ & $\begin{array}{r}607,8 \\
14.420,3 \\
4.9\end{array}$ \\
\hline Jumlah & 198,4 & $16.775,0$ & 356,0 & $1.664,2$ & 124,0 & $10.789,3$ & 40,2 & $4.513,8$ & 162,8 & $1.256,0$ & 94,7 & $1.165,8$ & \\
\hline
\end{tabular}

Konversi awal mangrove untuk pertanian adalah untuk perkebunan kelapa dan sawah di lahan basah pasang surut terjadi di sepanjang pantai Kalimantan dan Sumatera Timur (Davie \& Sumardja, 1997). Perkebunan kelapa sawit merupakan satu-satunya kegiatan tanaman pertanian skala besar yang saat ini meluas ke wilayah perairan asin tempat tumbuh mangrove. Namun, selama ledakan awal produksi minyak sawit antara tahun 1990 dan 2000, perkebunan kelapa sawit tidak menimbulkan ancaman serius bagi mangrove. Perkebunan (kelapa sawit) berkontribusi terhadap perubahan mangrove di Provinsi Riau sebesar 2\% dari tahun 2000 - 2012 (Ramdani \& Hino, 2013). Namun jika skenario sekarang ini masih diterapkan maka Ilman et al. (2016) memprediksi sebesar 30.000 -
97.000 hektar mangrove akan hilang selama dua dekade ke depan.

Sepanjang pantai timur Sumatera masyarakat lokal aktif memanfaatkan kayu mangrove. Kayu merupakan hasil hutan terpenting yang berasal dari mangrove dan banyak dimanfaatkan sebagai kayu bakar, cerocok dan bahan baku arang oleh penduduk setempat (Miswadi et al., 2017). Famili Rhizophoraceae dibuat menjadi arang di Riau dan diekspor ke Singapura (Choong et al., 1990). Bagi masyarakat lokal tidak banyak pilihan dalam kehidupan sehari-hari dan mangrove menjadi pilihan utama, terutama bahan bangunan, kayu bakar, infrastruktur dan perikanan (Ilman et al., 2016). Diperkirakan sebanyak 287 desa berada kawasan mangrove Provinsi Riau dan aktifitas masyarakat di desa-desa tersebut dapat mempengaruhi 
keberadaan mangrove antara $0.05 \%$ dan $0.16 \%$. (Prihatna et al., 2006)

Tujuh ibu kota kabupaten di Provinsi Riau berada di daerah pesisir dengan asosiasi infrastruktur seperti jalan, bandar udara, pelabuhan untuk menghubungkan mereka. Perluasan pembangunan menjadi salah satu ancaman utama terhadap mangrove. Pembangunan tidak selalu berdampak langsung seperti halnya eksploitasi kayu, tapi juga dapat menciptakan kerusakan yang lambat dan tidak dapat dipulihkan karena perubahan hidrologi (Ilman et al., 2016). Pada kajian lainnya Yan et al. (2017) menambahkan, setelah 30 tahun proses pengembangan lahan, luas lahan konstruksi perkotaan meningkat 3,5 kali lipat di pantai timur Sumatera sementara lahan pertanian, wilayah dengan intensitas pembangunan sedang ke atas masing-masing diperluas dari $22,02 \%-44,56 \%$, dan hal tersebut mempengaruhi keberadaan mangrove termasuk di Provinsi Riau.

\section{KESIMPULAN}

Mangrove Provinsi Riau tersebar sepanjang muara sungai dan garis pantai di tujuh kabupaten/kota. Mulai dari Kabupaten Rokan Hilir (bagian utara) hingga ke Kabupaten Indragiri Hilir (bagian selatan). Selama dua dekade $(2000-2019)$ luas dan sebaran mangrove di Provinsi Riau cenderung menurun dari 180.952,1 hektar menjadi 161.655,5 hektar. Rata-rata penurunan luas per tahun adalah 2.495,9 hektar. Penurunan tajam terjadi pada tahun 2009. Pada periode yang sama terjadi pengurangan luas mangrove sebesar 48.038,6 hektar, penambahan sebesar 15.998,5 hektar dan mangrove yang tetap seluas 145.656,96 hektar. Perubahan fungsi mangrove menjadi fungsi lainnya diakibatkan oleh faktor-faktor antropogenik.

Pemetaan mangrove menggunakan data yang lebih baik dan metode yang terukur akan lebih memastikan keberadaan sebaran dan eksistensi mangrove Riau.

\section{UCAPAN TERIMAKASIH}

Penulis mengucapkan terima kasih kepada Forest 2020 Indonesia sebagai penyedia data daring, yang digunakan dalam penelitian ini. Ucapan terima kasih disampaikan juga kepada reviewer atas komentar yang bijaksana dan konstruktif guna penyempurnaan tulisan ini.

\section{DAFTAR PUSTAKA}

Adrianto, H. A., Spracklen, D. V., Arnold, S. R., Sitanggang, I. S., \& Syaufina, L. (2020). Forest and Land Fires Are Mainly Associated with Deforestation in Riau Province, Indonesia. 12(1), 3. https://www.mdpi.com/2072-4292/12/1/3
Alongi, D. M., \& Mukhopadhyay, S. K. (2015). Contribution of mangroves to coastal carbon cycling in low latitude seas. Agricultural and Forest Meteorology, 213, 266-272.

https://doi.org/10.1016/j.agrformet.2014.10.005

Arifanti, V. B. (2020). Mangrove management and climate change: a review in Indonesia. IOP Conference Series: Earth and Environmental Science, 487, 012022. https://doi.org/10.1088/17551315/487/1/012022

Aziz, A. A., Thomas, S., Dargusch, P., \& Phinn, S. (2016). Assessing the potential of REDD+ in a production mangrove forest in Malaysia using stakeholder analysis and ecosystem services mapping. Marine Policy, 74, 6-17. http://dx.doi.org/10.1016/j.marpol.2016.09.013

Besset, M., Gratiot, N., Anthony, E. J., Bouchette, F., Goichot, M., \& Marchesiello, P. (2019). Mangroves and shoreline erosion in the Mekong River delta, Viet Nam. Estuarine, Coastal and Shelf Science, 226, 106263. https://doi.org/10.1016/j.ecss.2019.106263

Bunting, P., Rosenqvist, A., Lucas, R. M., Rebelo, L.M., Hilarides, L., Thomas, N., Hardy, A., Itoh, T., Shimada, M., \& Finlayson, C. M. (2018). The Global Mangrove Watch-A New 2010 Global Baseline of Mangrove Extent. Remote Sensing, 10(10), 1669. https://www.mdpi.com/20724292/10/10/1669

Cameron, C., Hutley, L. B., Friess, D. A., \& Munksgaard, N. C. (2019). Hydroperiod, soil moisture and bioturbation are critical drivers of greenhouse gas fluxes and vary as a function of landuse change in mangroves of Sulawesi, Indonesia. Science of The Total Environment, 654, 365-377. https://doi.org/10.1016/j.scitotenv.2018.11.092

Choong, E. T., Wirakusumah, R. S., \& Achmadi, S. S. (1990). Mangrove forest resources in Indonesia. Forest Ecology and Management, 33-34, 45-57. https://doi.org/10.1016/0378-1127(90)90183-C

Critchley, L. P., Bugnot, A. B., Dafforn, K. A., Marzinelli, E. M., \& Bishop, M. J. (2021). Comparison of wrack dynamics between mangrove forests with and without seawalls. Science of The Total Environment, 751, 141371.

https://doi.org/10.1016/j.scitotenv.2020.141371

Daniel, P. A., \& Robertson, A. I. (1990). Epibenthos of mangrove waterways and open embayments: Community structure and the relationship between exported mangrove detritus and epifaunal standing stocks. Estuarine, Coastal and Shelf Science, 31(5), 599-619. https://doi.org/10.1016/02727714(90)90015-J

Davie, J., \& Sumardja, E. (1997). The protection of forested coastal wetlands in Southern Sumatra: a regional strategy for integrating conservation and development. Pacific Conservation Biology, 3(4), 366-378. https://doi.org/10.1071/PC980366 
Garcia, M. R., \& Martins, C. C. (2021). A systematic evaluation of polycyclic aromatic hydrocarbons in South Atlantic subtropical mangrove wetlands under a coastal zone development scenario. Journal of Environmental Management, 277, 111421. https://doi.org/10.1016/j.jenvman.2020.111421

Giesen, W., Wulffraat, S., Zieren, M., \& Scholten, L. (2007). Mangrove guidebook for southeast asia. FAO and Wetlands International.

Giri, C., Ochieng, E., Tieszen, L. L., Zhu, Z., Singh, A., Loveland, T., Masek, J., \& Duke, N. (2011). Status and distribution of mangrove forests of the world using earth observation satellite data. Global Ecology and Biogeography, 20(1), 154-159. https://doi.org/10.1111/j.14668238.2010.00584.x

Goldberg, L., Lagomasino, D., Thomas, N., \& Fatoyinbo, T. (2020). Global declines in human-driven mangrove loss. Global Change Biology, 26(10), 5844-5855. https://doi.org/10.1111/gcb.15275

Hartini, S., Saputro, G. B., \& Niendyawati, d. (2010). Review on a national mangrove mapping: Case Study on the Indonesia Mangrove Mapping by BAKOSURTANAL Globe, 12(2), 146-150.

Ilman, M., Dargusch, P., Dart, P., \& Onrizal. (2016). A historical analysis of the drivers of loss and degradation of Indonesia's mangroves. Land Use Policy, 54, 448-459.

http://dx.doi.org/10.1016/j.landusepol.2016.03.0 10

Ilman, M., Wibisono, I., \& Suryadiputra, N. (2011). State of the Art Information on Mangrove Ecosystems in Indonesia.

https://doi.org/10.13140/RG.2.1.3967.9120

Jennerjahn, T. C. (2020). Relevance and magnitude of 'Blue Carbon' storage in mangrove sediments: Carbon accumulation rates vs. stocks, sources vs. sinks. Estuarine, Coastal and Shelf Science, 107027. https://doi.org/10.1016/j.ecss.2020.107027

Jhonnerie, R., Prianto, E., \& Oktorini, Y. (2007). Deteksi perubahan luasan hutan mangrove denan menggunakan penginderaan jauh dan sistem informasi geografis di Kota Dumai, Provinsi Riau. Torani, 17(2), 159-169.

Jhonnerie, R., Siregar, V., Nababan, B., Prasetyo, L., \& Wouthuyzen, S. (2014). Deteksi perubahan tutupan mangrove menggunakan citra Landsat berdasarkan klasifikasi hibrida di Sungai Kembung, Pulau Bengkalis, Provinsir Riau. Jurnal Ilmu dan Teknologi Kelautan Tropis, 6, 191-206.

Margono, B. A., Usman, A. B., Budiharto, \& Sugardiman, R. A. (2016). Indonesian's forest resources monitoring. Indonesian Journal of Geography, 48(1), 7 - 20. https://jurnal.ugm.ac.id/ijg/article/download/12496/9041

Marley, G. S. A., Deacon, A. E., Phillip, D. A. T., \& Lawrence, A. J. (2020). Mangrove or mudflat: Prioritising fish habitat for conservation in a turbid tropical estuary. Estuarine, Coastal and Shelf Science, $240,106788$.

https://doi.org/10.1016/j.ecss.2020.106788

Martosubroto, P., \& Naamin, N. (1977). Relationship between tidal forests (mangroves) and commercial shrimp prodictution in Indonesia. Marine Research in Indonesia, 18, 81-86.

https://doi.org/10.14203/mri.v18i0.363

Miswadi, Ramses \& R. Jhonnerie. 2017. Pemanfaatan Kayu Mangrove oleh Masyarakat Suku Asli Sungai Liong Pulau Bengkalis. Dinamika Maritim, 1(1): 35-39.

Momose, K. \& T. Shimamura. 2002. Environment and People of Sumatran Peat Swamp Forest I: Distribution and Typology of Vegetation, South East Asia Study 40: 72-84.

Mustafa Kamal, A. H., Hoque, M. M., Idris, M. H., Billah, M. M., Karim, N. U., \& Bhuiyan, M. K. A. (2020). Nutrient properties of tidal-borne alluvial sediments from a tropical mangrove ecosystem. Regional Studies in Marine Science, 36, 101299. https://doi.org/10.1016/j.rsma.2020.101299

Prihatna, M. S., Nurdiana, A., \& Luky, A. (2006). Analisis Ekonomi Alternatif Pengelolaan Ekosistem Mangrove Kecamatan Barru, Kabupaten Barru. Buletin Ekonomi Perikanan, 6(3).

Rahadian, A., Prasetyo, L. B., Setiawan, Y., \& Wikantika, K. (2019). Tinjauan historis data dan informasi luas mangrove Indonesia. Media Konservasi, 24(2), 163 - 178.

Ramdani, F., \& Hino, M. (2013). Land Use Changes and GHG Emissions from Tropical Forest Conversion by Oil Palm Plantations in Riau Province, Indonesia. PLOS ONE, 8(7), e70323. https://doi.org/10.1371/journal.pone.0070323

Rasquinha, D. N., \& Mishra, D. R. (2020). Impact of wood harvesting on mangrove forest structure, composition and biomass dynamics in India. Estuarine, Coastal and Shelf Science, 106974. https://doi.org/10.1016/j.ecss.2020.106974

Richards, D. R., \& Friess, D. A. (2016). Rates and drivers of mangrove deforestation in Southeast Asia, 2000-2012. Proceedings of the National Academy of Sciences, 113(2), 344-349. https://doi.org/10.1073/pnas.1510272113.

Silvius, M. J., Steeman A. P. J. M., Berczy E. T., Djuharsa E., Taufik A. 1987. The Indonesian Wetland Inventory. A Preliminary Compilation of Existing Information on Wetlands of Indonesia. Bogor.

Spalding, M., Kainume, M., \& Collins, L. (2010). World atlas of mangroves. British: Routledge, pp 336.

Sukardjo, S. (2000). Indonesia: mangrove-friendly aquaculture. In J. H. Primavera, L. M. B. Garcia, M. T. Castaños, \& M. B. Surtida. Mangrove-Friendly Aquaculture. Philippines: SEAFDEC Aquaculture Departement. 
Van Oudenhoven, A. P. E., Siahainenia, A. J., Sualia, I., Tonneijck, F. H., van der Ploeg, S., de Groot, R. S., Alkemade, R., \& Leemans, R. (2015). Effects of different management regimes on mangrove ecosystem services in Java, Indonesia. Ocean \& Coastal Management, 116, 353-367. https://doi.org/10.1016/j.ocecoaman.2015.08.003

Yan, J., Su, F., \& Wang, M. (2017). The development processes and regional differentiation of both banks of the Strait of Malacca during 1980-2010. Ocean \& Coastal Management, 139, 141-152. https://doi.org/10.1016/j.ocecoaman.2017.02.012
M., Castellanos-Galindo, G. A., Cunha-Lignon, M., Dahdouh-Guebas, F., Diele, K., Parrett, C. L., Dwyer, P. G., Gair, J. R., Johnson, A. F., Kuguru, B., Savio Lobo, A., Loneragan, N. R., LongleyWood, K., Mendonça, J. T., Meynecke, J.-O., Mandal, R. N., Munga, C. N., Reguero, B. G., Rönnbäck, P., Thorley, J., Wolff, M., \& Spalding, M. (2020). Fishers who rely on mangroves: Modelling and mapping the global intensity of mangroveassociated fisheries. Estuarine, Coastal and Shelf Science, 106975.

https://doi.org/10.1016/j.ecss.2020.106975

Zu Ermgassen, P. S. E., Mukherjee, N., Worthington, T. A., Acosta, A., Rocha Araujo, A. R. d., Beitl, C. 